\title{
Aproximación al efecto de la resistividad del hormigón en la corrosión de armaduras embebidas en hormigón
}

\section{Approach to the effect of concrete resistivity in the corrosion of rebars in concrete}

\begin{abstract}
RESUMEN
La resistividad del hormigón se ha venido considerando como uno de los factores que afectan a la velocidad de corrosión de las armaduras, aunque, hasta ahora, la única relación encontrada ha sido la establecida entre los potenciales y la resistividad para acero embebido en hormigón contaminado por cloruros.
\end{abstract}

En este trabajo se establecen comparaciones entre velocidad de corrosión de las armaduras, medida a través del método de determinación de la Resistencia de Polarización, y los datos de resistencia eléctrica medidos a través de la compensación de caída óhmica.

Los resultados de $i_{\text {corr }}$ y $R_{\text {ohm }}$ se han medido en armaduras embebidas en mortero fabricado con tres tipos de cemento a los que se ha sometido a un proceso de carbonatación acelerada.

La relación entri $i_{\text {corr }}$ y $R_{\text {corr }}$ es muy similar en todos los casos y sugiere que la resistencia del hormigón puede actuar como un factor controlante de la velocidad de corrosión de las armaduras.

\author{
C. ALONSO y C. ANDRADE \\ IETCC/CSIC \\ Serrano Galvache s/n, 28033-Madrid \\ J. A. GONZALEZ \\ Centro Nacional de Investigaciones Metalúrgicas \\ MADRID/ESPAÑA
}

\section{$S U M M A R Y$}

The concrete resistivity has been considered as a factor which affects the corrosion rate of the rebars. Untill now the only relation found has been stablished between potentials and resistivity for steel embedded in Chloride contaminated concrete.

In this paper a comparison between corrosion rate of rebars, determined from Polarization Resistance method, and Electrical Resistance data measured through the electronic compensation of the ohmic drop are given.

The results of $i_{\text {corr }}$ and $R_{\text {ohm }}$ has been measured for rebars embedded in mortar made with three different types of cement. The specimens were submited to an accelerated carbonation.

The relation between $i_{\text {corr }}$ and $R_{\text {nm }}$ is quite similar in all the cases and suggests that the concrete electrical resistivity may be a controling factor of the corrosion rate of the rebars.

\section{INTRODUCCION}

El acero embebido en el hormigón está protegido contra la corrosión gracias al elevado carácter alcalino de la solución encerrada en los poros. Sin embargo, determinadas circunstancias pueden destruir esta capa protectora provocando la corrosión activa del acero. Los dos principales factores que pueden provocar esta situación son la presencia de iones agresivos (principalmente los cloruros) y la carbonatación del hormigón.

Cuando el acero se corroe activamente dentro del hormigón, generalmente se acepta que es

\section{INTRODUCTION}

The alkaline nature of the concrete pore solution provides high protection against corrosion of the ambedded steel. However, some circustances may disrupt the protective layer causing active corrosion of the steel. The two main factors which may provoke this situation are the presence of aggressive ions (mainly chlorides) and the carbonation of the concrete.

When steel actively corrodes inside the cocrete it is usually stated that the $\mathrm{O}_{2}$ availability is the 
el $\mathrm{O}_{2}$ disponibie el factor controlante de ia velocidad de corrosión. Sin embargo, en trabajos previos (1) que fueron publicados en 1980 se presentaron resultados en ios que se demostraba que eran los cambios encontrados en el proceso anódico los responsables de las diferentes tendencias en los valores de $E_{\text {corr }} \mathrm{e}$ $\mathrm{i}_{\text {corr }}$ (controi anódico). Posteriormente, Page y Hawdahl (2) apoyaron este hecho basándose en experimentos usando humo de sílice.

El acceso de oxígeno solamente controla la velocidad de corrosión (control catódico) cuando el hormigón está sumergido en agua, bajo el suelo o cuando el recubrimiento del hormigón armado es $\geq 3-4 \mathrm{~cm}$ (donde los poros pueden estar saturados continuamente). En hormigón aireado, el flujo de oxígeno disponibie al nivel de las armaduras es siempre io suficientemente elevado como para soportar la corriente anódica, por lo tanto, el control catódico no se produce en estructuras aireadas. Para demostrar este argumento los autores están realizando varios experimentos, cuyos resultados se publicarán en trabajos futuros.

Sin embargo, la atención debería centrarse en otro factor que también ha sido considerado como un agente controlante de la velocidad de corrosión, este es, la resistencia eléctrica del hormigón. Hace muchos años Stratfuil y otros (3) relacionaron este parámetro con la corrosión activa de las armaduras en hormigón contaminado por cloruros.

La resistencia eléctrica del hormigón ha sido estudiada por muchos autores (4) (5) (6) (7) obteniéndose resultados muy distintos para las mismas condiciones de servicio. Las diferencias se atribuyeron a las distintas técnicas empleadas, sin embargo, no se han encontrado trabajos que asociaran la resistividad con la velocidad de corrosión.

En un trabajo reciente (8) los autores encontraron una relación en mortero entre: la humedad ambiental, la resistencia eléctrica (medida a través de la compensación electrónica de la caída óhmica con un potenciostato) y la velocidad de corrosión del acero (determinada por las medidas de la Resistencia de Polarización). Se encontró una relación lineal cuando la humedad ambiental cambiaba del $40 \%$ al $100 \%$. En presencia de cioruros (corrosión activa) la pendiente de esta recta fue alrededor de -1 , pero en morteros sin aditivos apareció una línea casi horizontal (la velocidad de corrosión se dibujó en ordenadas) ya que la $i_{\text {corr }}$ casi no cambia cuando el acero está pasivo.

En el presente trabajo se presentan resultados de un experimento similar donde la controlling factor of the corrosion rate. However, in a previous paper (1) published in 1980 we presented results demostrating that the changes in the anodic process were responsable for the different trends found in ihe $E_{\text {corr }}$ and $i_{\text {corr }}$ values (anodic control). Later, Page and Havdahl (2) supported this finding based on experiments using silica fume.

The access of oxygen controls the corrosion rate (cathodic control) only when the concrete is under water or soil or when the reinforcement has a cover $\geq 3.4 \mathrm{~cm}$ (where the pores may be permanently saturated). In aerated concrete the flux of oxygen available at the level of the reinforcements is always high enough to support the anodic current, therefore, no cathodic control is produced in aerated structures. To demostrate these arguments the authors are carrying out various experiments, the results of which will be published in a future paper.

Nevertheless, attention should be focused on another factor which has also been considered as a controlling agent of the corrosion rate, that is, the electrical resistivity of the concrete. Many years ago Stratfull et al (3) related this parameter with the active corrosion of the reinforcements in chloride contaminated concrete.

The electrical resistivity of the concrete has been studied by many authors (4) (5) (6) (7) and a wide range of different values for the same service conditions were obtained. The differences were attributed to the different cell types and techniques used, however, no paper were found which associated the resistivity with the corrosion rate.

In a recent paper (8) the authors showed the relation found in mortar between the ambient humidity, the electrical resistivity (measured by means of the electronic compensation of the ohmic drop of a potentiostat) and the corrosion rate of steel (determined from polarization resistance measurements). A linear relation-ship was found when the ambient humidity moves from $40 \%$ to $100 \%$. In the presence of chlorides (active corrosion) the slope of this line was about -1 , but in the mortar without admixtures a quasi-horizontal line appeared (the corrosion rate was plotted as ordinates) since almost no changes in $i_{\text {corr }}$ are produced when steel is passivated.

In the present paper a similar experiment is presented but where the carbonation acts as 
carbonación es aquí el factor despasivante que provoca la corrosión en estado activo de las armaduras. Aunque en la literatura se hacen frecuentes referencias al aumento de la resistividad eléctrica del hormigón debido a la carbonatación, son pocos los datos precisos encontrados, y por consiguiente, este parámetro no se relacionó cuantitativamente con la velocidad de corrosión.

\section{METODO EXPERIMENTAL}

Se fabricaron probetas de mortero de $2 \times 5,5 \times 8 \mathrm{~cm}$ de relaciones $\mathrm{c} / \mathrm{a}=1 / 3 \mathrm{y}$ a/c $=0,5$ con los cementos: P-350Y, pozolánico y de cenizas. En las probetas se embebieron dos barras idénticas de acero y otra de grafito. El área de ensayo en las armaduras fue aproximadamente de $6 \mathrm{~cm}^{2}$.

Después de un período de curado de 28 días en una cámara al $100 \%$ de humedad relativa (H.R.) y $20 \% \pm 2{ }^{\circ} \mathrm{C}$., las probetas se sometieron a un proceso de carbonatación acelerada en una cámara saturada de $\mathrm{CO}_{2}$ con humedades entre (50-70 \%). La evolución de la carbonatación se determinó pesando las probetas durante el proceso. Se consideró que la carbonatación había finalizado cuando el peso de las probetas dejó de aumentar.

Posteriormente a la carbonatación las probetas se sometieron a sucesivos periodos de humedad: al $100 \%, 50 \%$ H.R. e inmersión parcial (P.S.).

Durante el ensayo se controló el potencial de corrosión y la resistencia de polarización, $R_{p}$. En las medidas del $E_{\text {corr }}$ se empleó un electrodo de referencia de calomelanos.

Los valores de $R_{p}$ se determinaron por el método de Stern y Geary. Se aplicó una polarización de $-10 \mathrm{a}+10 \mathrm{mv}$ alrededor del $E_{\text {corr }}$ a una velocidad de barrido de $10 \mathrm{mv} / \mathrm{min}$. La intensidad de corrosión se calculó siguiendo la ecuación:

$$
\mathrm{I}_{\text {corr }}=(\triangle I / \triangle E) \times B=B / R_{p}
$$

Donde $\mathrm{B}$ es una constante que toma valores de $26 \mathrm{mv}$ para corrosión activa y 52 para corrosion en estado pasivo. El equipo empleado se muestra en la figura 1 , mientras que en la figura 2 aparece la disposición de los electrodos.

El potenciostato tiene una compensación electrónica de la caída óhmica (realimentación positiva) cuyos valores se registran como "resistencia eléctrica compensada". the depassivating factor which supports the active corrosion of the rebars. Although frequent references are made in the literature about the increase in the electrical resistivity due to carbonation, very little information on precise values has been found and, consequently, this parameter was not quantitatively related with the corrosion rate.

\section{EXPERIMENTAL PROCEDURE}

Mortar specimens of $2 \times 5.5 \times 8 \mathrm{~cm}$ with $c / s=1 / 3$ and $w / c=0.5$ were prepared. SRPC pozzolanic and fly ash cements were used. Two steel bars and a carbon bar were embedded in mortar specimens. The test area of the bars was aproximately $6 \mathrm{~cm}^{2}$.

After a cured period of 28 days in a chamber at $100 \%$ of relative humidity (R.H.), and $20 \pm 2^{\circ} \mathrm{C}$ the specimens were submited to an accelerated carbonation process in a chamber saturated with $\mathrm{CO}_{2}$ with a humidity between (50-70\%). The carbonation evolution was determined by weighing the specimens during the process. The carbonation was considered over when the weight ceases to increase.

After the specimens were carbonated, they were submitted to consecutive humidity periods at $100 \%, 50 \% \mathrm{RH}$ and partial immersion (P.I.).

Corrosion potential and polarization resistance, $R_{p}$, measurements were recorded during the test. A calomel reference electrode was used for $E_{\text {corr }}$ ones.

The $R_{p}$ value was determined by Stern and Geary's method. A polarization from - 10 to $+10 \mathrm{mV}$ was applied to the $E_{\text {corr }}$ at a sweep rate of $10 \mathrm{mV} / \mathrm{min}$. The corrosion intensity was calculated from the following equation:

$$
I_{\text {coor }}=(\triangle I / \triangle E) \times B=B / R_{p}
$$

where $B$ is a constant taking values of $26 \mathrm{mV}$ for active corrosion and $52 \mathrm{mV}$ for passive corrosion. The equipment used is shown in figure 1, while figure 2 presents the disposition of the electrodes.

The potentiostat has an electronic compensation of the ohmic drop (positive feedback) whose values are recorded as "compensated electrical resistance". 
Este método permite la medida de la caída óhmica entre el electrodo de la referencia y el de trabajo. El cotraeléctrodo es necesario para introducir la corriente y cerrar el circuito.

La distancia entre electrodos fue siempre la misma en cada medida. El electrodo de referencia se colocó perpedicular a la superficie del mortero a $0,7 \mathrm{~cm}$ del contraelectrodo y aproximadamente a $2 \mathrm{~cm}$ del electrodo de trabajo como se aprecia en la figura 2 .

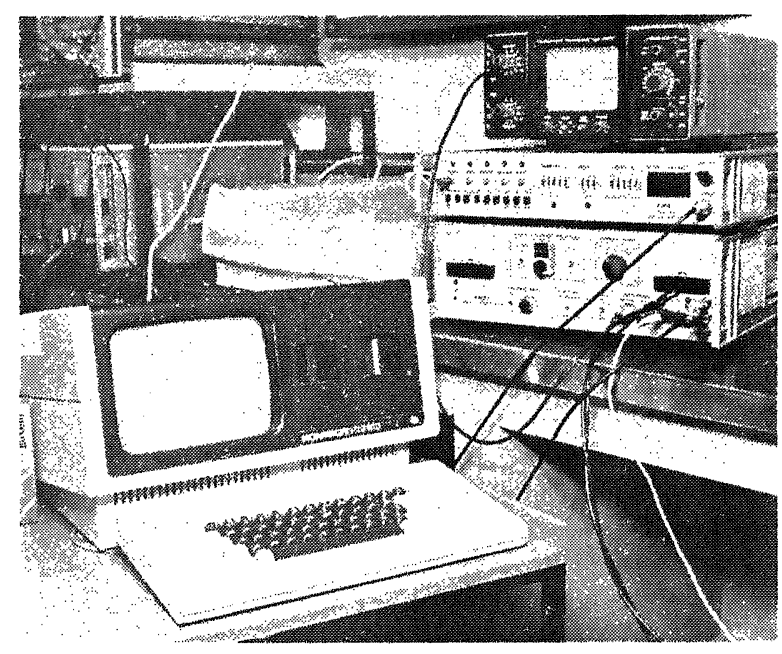

Fig. 1.-Equipo usado para las medidas de $R_{p}$ y $R_{\text {ohm }}$. Fig. 1.-Equipment used for $R_{p}$ and $R_{\text {ohm }}$ measurements.

\section{RESULTADOS}

En las figuras 3, 4 y 5 se representa la evolución con el tiempo de las variables a estudiar, $i_{\text {corr }}$ y $R_{\text {ohm }}$ para cada tipo de cemento empleado.

La $i_{\text {corr }}$ decrece desde el comienzo de ensayo hasta el final del período de curado. Cuando la carbonatación acelerada comienza, la $i_{\text {corr }}$ aumenta escalonadamente, para alcanzar valores al final de la carbonatación alrededor de $0,2 \mu \mathrm{A} / \mathrm{cm}^{2}$. Posteriormente, la $i_{\text {corr }}$ aumenta al hacerlo ia H.R. Así, la velocidad de corrosión es bastante elevada $\left(3-10 \mu \mathrm{A} / \mathrm{cm}^{2}\right)$ cuando las probetas se situan en condiciones de inmersión parcial, pero tienen valores muy bajos cuando están al $50 \%$ H.R. En esta humedad ambiental los valores de $\mathrm{i}_{\text {corr }}$ son incluso más bajos que cuando el acero está embebido en mortero no carbonatado a la misma H.R.
This method permits the measurement of the ohmic drop between reference and working electrode. A counter electrode is needed to close the circuit and to introduce the current

The distance beiween electrodes was always the same for each measurement. The reference electrode was localed perpendicular the surface of the mortar specimen, at $\simeq 0.7 \mathrm{~cm}$

from the counter and $\simeq 2 \mathrm{~cm}$ from the working electrode as figura 2 shows.

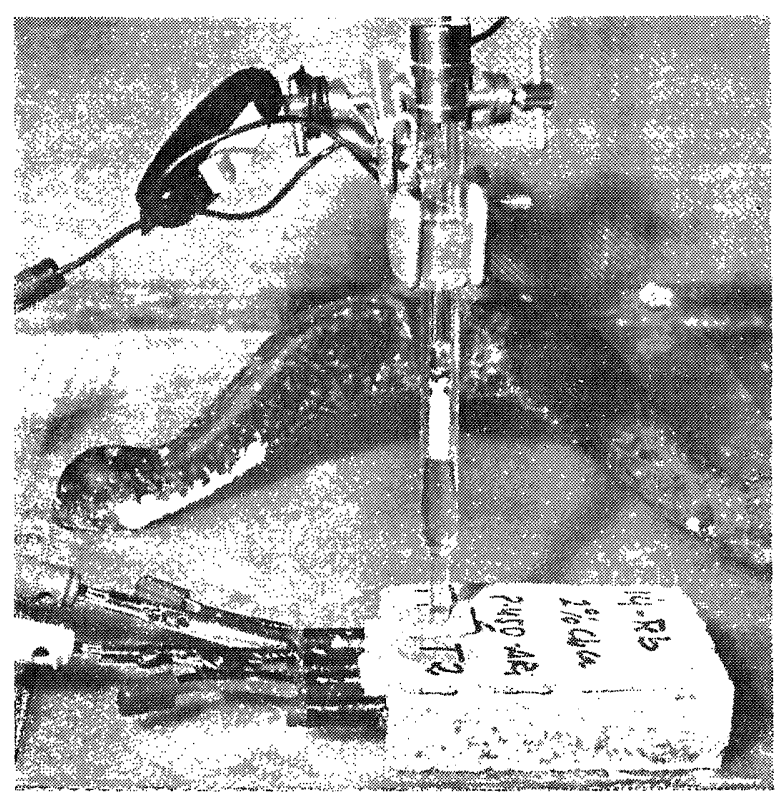

Fig. 2.-Disposición de los electrodos para las medidas.

Fig. 2.-Disposition of the electrodes for measurements.

\section{RESULTS}

Figures 3,4 and 5 represent the evolution over time of the variables under study, $I_{\text {corr }}$ and $R_{\text {ohm }}$ for each of the cement types used.

The $i_{\text {corr }}$ decreases from the beginning of the test to the end of the curing period. When accelerated carbonation starts, the $i_{\text {corr }}$ steeply increases to reach values of about $0.2 \mu \mathrm{AVcm}{ }^{2}$ at the end of the carbonation period. Later, the $i_{\text {corr }}$ increases as the RH does. Thus, the corrosion rates are quite high $\left(3-10 \mu \mathrm{A} / \mathrm{cm}^{2}\right)$ when the specimens are held in partial immersion condition, but they present very low values when they are at $50 \% \mathrm{RH}$. In this ambient humidity the $i_{\text {corr }}$ values are even lower that when the steel is embedded in non-carbonated mortar at the same $R H$. 
La tendencia de la resistencia eléctrica compensada es también similar para los tres tipos de cemento empleado y evoluciona de una forma parecida a lo largo del ensayo. Durante el periodo de curado la Rohm aumenta continuamente y de forma dramática lo hace (alrededor de dos o tres órdenes de magnitud) cuando comienza la carbonatación. Por lo tanto, la evolución de la Rohm es simultánea e inversa a la $\mathrm{i}_{\text {corr }}$ : Aumenta cuando la humedad ambiental decrece y viceversa.

La relación de los valores de la $\mathrm{i}_{\text {corr }}$ con los de $R_{\text {ohm }}$ para los tres tipos de cemento ensayado, se representa en la figura 6 . Los valores representados son los obtenidos después de la carbonatación cuando hay corrosión activa.

En este caso, fue posible ajustar una línea recta de pendiente $-1,1$, indicando una relación lineal entre los dos parámetros considerados en un diagrama logarítmico.

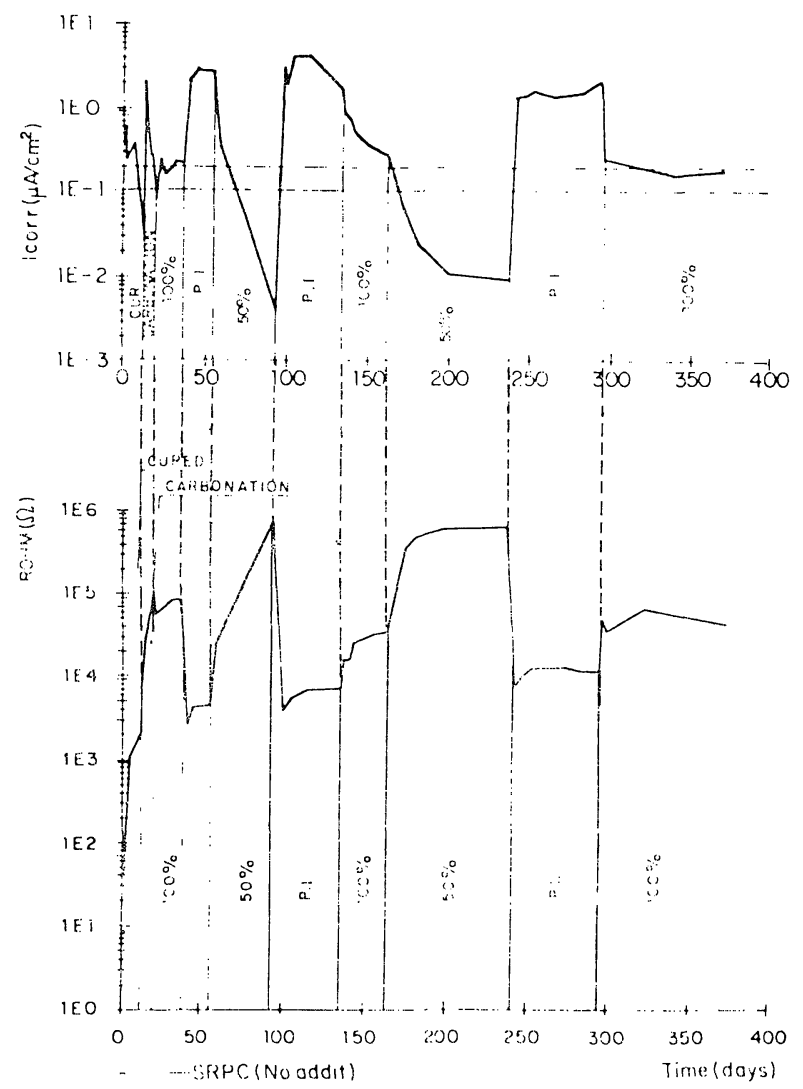

Fig. 3.-Intensidad de corrosión (i $\left.i_{c o r r} \mu \mathrm{A} / \mathrm{cm}^{2}\right)$ y caída ónmica $\left(\mathrm{F}_{\mathrm{n} m} \Omega\right.$ ) en función del tiempo para barras de acero embebidas mortero de cemento P-350Y carbonatado.

Fig. 3.-Corrosion intensity ( $\left.i_{\text {corr }} \mu \mathrm{A} / \mathrm{cm}^{2}\right)$ and ahmic drop $\left(R_{\text {ohm }} \Omega\right)$ versus time for bars embedded in SRPC carbonated mortar.
The trend of the compensated electrical resistance is also similar for the three cements employed and evolues in a similar manner during the esperiment. During the curing period the Rohm increases continuously and dramatically increases (about twothree orders of magnitude) when the carbonation starts. Then, the evolution of Rohm is simultaneous and inverse to that of $i_{\text {corr }}$ : It increases when ambient humidity decreases and viceversa.

The relation of $i_{\text {corr }}$ values with Rohm values for the three mortars tested, is shown in figure 6. The values represented are those compiled after the carbonation period when active corrosion is produced.

In this case, it was possible to fit a straight line of slope - 1.1, indicating a linear relationship between the two parameters considered.

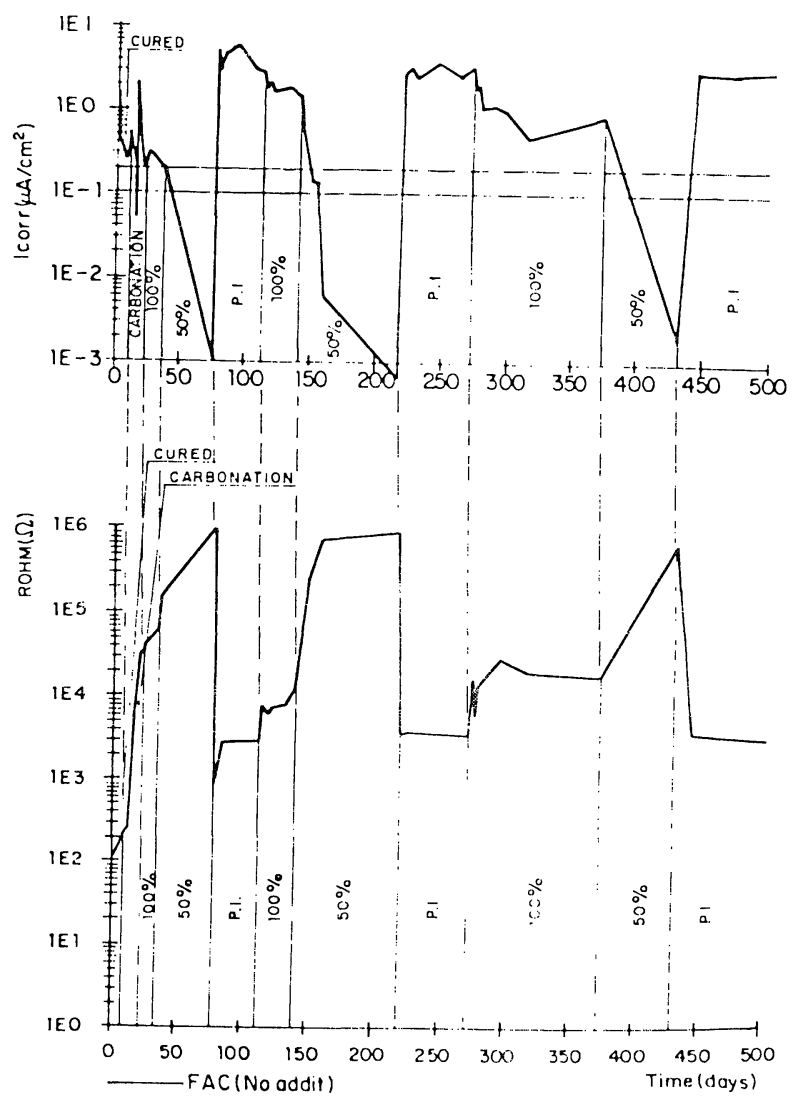

Fig. 4.-Intensidad de corrosion ( $i_{\operatorname{cor}} \mu \mathrm{A} / \mathrm{cm}^{2}$ ) y caída óhmica $\left(R_{\text {ohm }} \Omega\right)$ en función del tiempo para barras de acero embebidas en mortero de cemento de cenizas carbonatado.

Fig. 4.-Corrosion intensity $\left(i_{\text {corr } \mu \mathrm{A} / \mathrm{cm}^{2}}\right)$ and ohmic drop $\left(R_{\text {ohm }} \Omega\right)$ versus time for bars embedded in FAC carbonated mortar. 


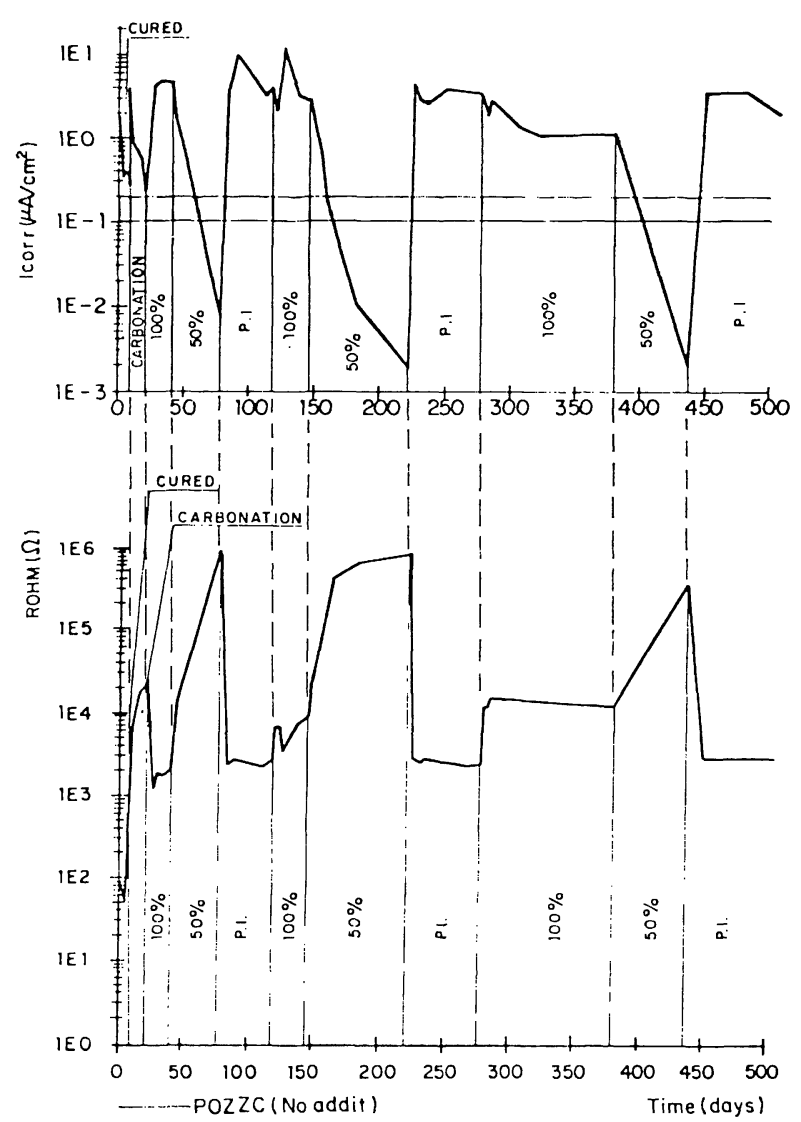

Fig. 5.-Intensidad de corrosión $\left(i_{\text {corr }} \mu \mathrm{A} / \mathrm{cm}^{2}\right)$ y caída ónmica $\left(R_{\mathrm{ohm}} \Omega\right)$ en función del tiempo para barras de acero embebidas en mortero de cemento puzolánico carbonatado.

Fig. 5.-Corrosion intensity $\left(i_{\text {corr }} \mu \mathrm{A} / \mathrm{cm}^{2}\right)$ and ohmic drop $\left(R_{\text {ohm }} \Omega\right)$ versus time for bars embedded in pozz $C$ carbonated mortar.

\section{DISCUSION}

Si se considerará el acceso de oxígeno como uno de los factores que controla la velocidad de corrosión de las armaduras en hormigón, se registrarian velocidades de corrosión más elevadas al $50 \%$ H.R. comparadas con $100 \%$ - I.P. porque el $\mathrm{O}_{2}$ alcanza la armadura más fácilmente a H.R. tan bajas. Sin embargo, está perfectamente aceptado que incluso si el hormigón está carbonatado como es el caso de estos experimentos, a esta humedad ambiental no se registran velocidades de corrosión significativas.

El mismo argumento puede usarse para comparar el comportamiento entre $100 \%$ H.R. e inmersión parcial. En la última condición el acceso de $\mathrm{O}_{2}$ parece estar más dificultado que al $100 \%$ H.R., sin embargo las velocidades de corrosión son mayores que al $100 \%$ H.R.

Los resultados presentados aquí parecen indicar que la resistencia eléctrica puede ser

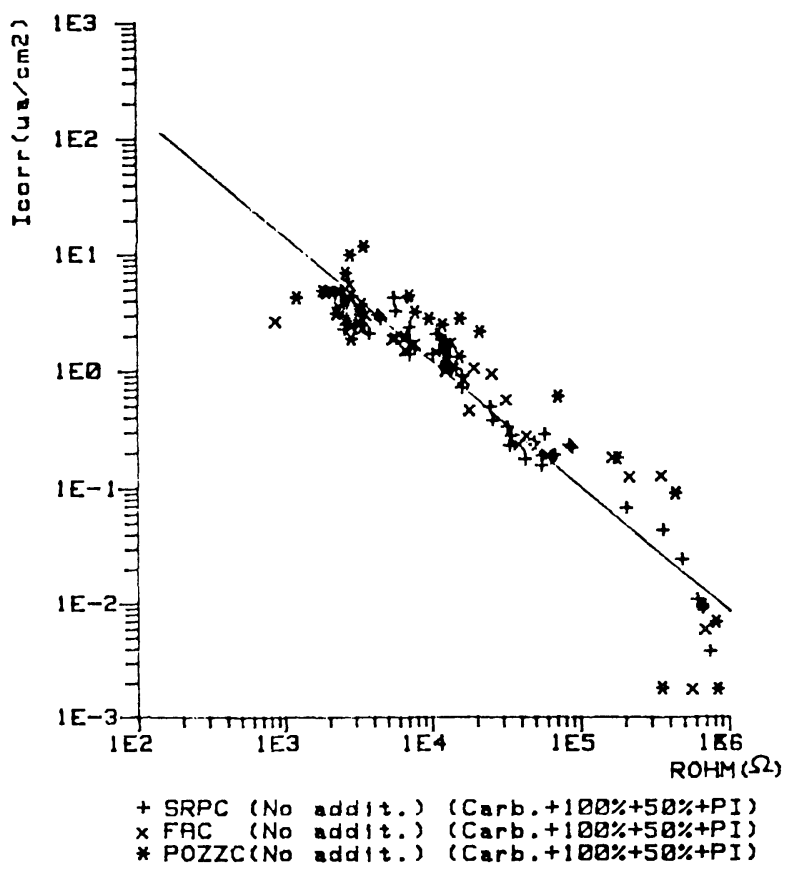

Fig. 6.-Intensidad de corrosión ( $\left.i_{\text {corr }} \mu \mathrm{A} / \mathrm{cm}^{2}\right)$ en función de la caída óhmica $\left(R_{\text {ohm }} \Omega\right)$ para barras de acero embebidas en morteros carbonatados de cementos.

Fig. 6.-Corrosion intensity $\left(i_{\text {corr }} \mu A / \mathrm{cm}^{2}\right)$ versus ohmic drop $\left(R_{\text {ohm }} \Omega\right)$ for bars embedded in SRPC, FAC and Pozz $C$ carbonated mortar.

\section{DISSCUSION}

If the access of oxygen is considered as one of the factors that may control the corrosion rate of rebars in concrete, a higher corrosion rate would be recorded at $50 \% \mathrm{RH}$ compared with $100 \%$ or P.I. because the $\mathrm{O}_{2}$ reaches the bar casier at this low RH. However, it is a generally accepted statement that even if the concrete is carbonated as is the case in the present experiments, at this ambient humidity no significant corrosion rates are recorded.

The same argument may be used for the comparison between the behaviour in $100 \%$ $\mathrm{RH}$ and that in P.I. in the latter condition, the access of $\mathrm{O}_{2}$ seems to be more difficult than at $100 \% \mathrm{RH}$, however the corrosion rates are higher in $100 \% \mathrm{RH}$.

The results shown here seem to indicate that the electrical resistivity may be the factor 
el factor que determine la continuación o cese de la velocidad de corrosión.

La conductividad eléctrica en el hormigón depende principalmente del transporte iónico a través de los poros. Sin embargo, hormigones más poderosos y permeables tendrían una menor resistividad, permitiendo así que se desarrollarán velocidades de corrosión más elevadas y viceversa.

Este argumento es consistente con el hecho de que la resistencia eléctrica está afectada principalmente por: la saturación de agua de los poros (equivalente a la porosidad abierta) como ha sido argumento por otros autores (3) (6) y, en menor importancia, por el tamaño máximo de agregado, la relación a/c y el grado de hidratación (6).

Cuando el mortero se carbonata, se precipita carbonato cálcico a partir de $\mathrm{Ca}(\mathrm{OH})_{2}$ y se forma también sílice, alúmina y óxido férrico. La solución contenida en los poros de un hormigón completamente carbonatado parece ser una solución diluida en bicarbonatos que debería tener una mayor resistividad que la solución alcalina de los poros. Sin embargo el aumento de la resistividad que permite el proceso de carbonatación puede ser atribuido a la precipitación de $\mathrm{CaCO}_{3}$ y sílice, alúmina, etc. que reduce la porosidad y a la precipitación de diferentes iones del agua de los poros.

Aunque puede concluirse por estas opiniones que la medida de la resistividad a pie de obra puede ser un método sencillo para calcular la velocidad de corrosión de las armaduras, una simple extrapolación es arriesgada, ya que deberían hacerse experimentos más minuciosos con diferentes tipos de hormigón para encontrar una relación biunívocą entre resistividad y velocidad de corrosión.

Además en estructuras reales la carbonatación puede no ser nivelada y en algunas zonas el acero puede permanecer pasivo, induciendo macrocélulas cuya actividad podría no detectarse midiendo la resistividad eléctrica local.

En trabajos previos se ha explicado que la zona rayada de los diagramas $i_{\text {corr }}$ tiempo entre $0,1,-0,2 \mu \mathrm{A} / \mathrm{cm}^{2}$ indica el límite entre estados activos y pasivos.

Este límite ha sido establecido por nuestra experiencia en este tipo de medidas. Si este límite se extrapola en la figura 6 , valores de $50.000-100.000 \Omega$ resultan como un posible límite de resistividad en hormigón carbonatado que permite que la corrosión progrese. which determines the cotinuation or cessation of the corrosion rate.

The electrical conductivity in the concrete is mainly due to ionic transport through the pore-net. Therefore a more porous and permeable concrete would have a lower resistivity, thus allowing higher corrosion rates to develop and viceversa.

This argument is consistent with the fact that electrical resistivity is mainly affected by: the pore water saturation (equivalent to the open porosity) as it has been reported by other authors (3) (6) and, in lesser importance, by the maximum aggregate size, the $\mathrm{w} / \mathrm{c}$ ratio, and the degree of hydration (6).

When the mortar is carbonated, calcium carbonate is precipitated from the $\mathrm{Ca}(\mathrm{OH})_{2}$ and silica, alumina and ferric oxydes are also formed. The solution contained in the pores of a completely carbonated concrete seems to be a dilute solution of bicarbonates, which should have a higher resistivity than the alkaline pore solution. Therefe the increase in the resistivity owing to the carbonation process may be attributed to the precipitacion of $\mathrm{CaCO}_{3}$ and silica, alumina, etc. which reduce the porosity and the precipitation of different ions from the pore water.

Although it might be concluded from these opinions that the on-site measurement of the resistivity may be an easy method to calculate the corrosion rate of the reinforcements, such, a simple extrapolation is risky, since a more through set of experiments with different types of concrete should be made to find a biunivocal relation between resistivity and corrosión rate.

Moreover, in real structures the carbonation may not be uneven and some zones of the steel may remain passivated, inducing macrocells whose activity could not be detected measuring the local electrical resistivity.

In previous works we have explained that the shaded zone shown in the $i_{\text {corr }}$ time plot between 0.1-0.2 $\mu \mathrm{A} / \mathrm{cm}^{2}$ indicates the boundary between active and passive steel states.

This boundary has been established by our experience in these types of measurements. If this limit is extrapolated in figure 6 , values of 50.000-100.000 $\Omega$ result as the possible limit of resistivity in carbonated mortar which allows corrosion to develop. 


\section{CONCLUSIONES}

Aunque se necesitan experimentos más minuciosos para verificar y soportar los argumentos que aquí se presentan, se pueden extraer algunas conclusiones preliminares:

1. De la comparación de la $i_{\text {corr }} y$ resistividad eléctrica puede deducirse que el límite de la resistencia en un hormigón carbonatado $(a / c=0,5$ y $c / a=1 / 3)$ es alrededor de $10^{4} \Omega$ por encima de este límite la corrosión no se desarrolla.

2. La resistividad eléctrica parece ser el factor que controla la velocidad de corrosión de armaduras cuando la corrosión es activa. Cuando el acero está pasivo, la resistividad no afecta al proceso y la velocidad de corrosión es independiente de él.

3. La humedad ambiental es la que afecta principalmente a la resistividad en mortero carbonatado, y por consiguiente a la velocidad de corrosión cuando el acero se esta corroyendo. Las condiciones de inmersión parcial se han presentado como las más agresivas en estos ensayos.

\section{CONCLUSIONS}

Although further experiments are needed to verify and completely support the arguments here presented, some preliminary conclusions may be drawn:

1. From the comparison of $i_{\text {corr }}$ and electrical resistivity it may be deduced that the limit value of resistivity in carbonated mortar $(w / c$ ratio of 0.5 and $c / s a n d=1 / 3$ ) is about $10^{4} \Omega \cdot \mathrm{cm}$. Above this limit no significant corrosion may develop.

2. The electrical resistivity seems to be the factor which controls the corrosion rate of the reinforcements when active corrosion is in progress. When the steel is passivated, the resistivity does not affect the process and the corrosion rate is independent of it.

3. The ambient humidity highly influences the resistivity in carbonated mortar, and consequently the corrosion rate when the steel is corroding. The partial immersion conditions have shown themselves to be the most aggresive ones in the present tests.

\section{REFERENCES}

(1) GONZALEZ, J. A., ALGABA, S. and ANDRADE, C.: Br. Corrs. J. Vol. 15, pp. 135 (1981).

(2) PAGE C. L. and HAVDHL, J.: Materiaux et Constructions, Vol. 18, N.․ 103, pp. 41 (1985)

(3) STRATFULL, R. F.: Materials protection, pp. 29, March (1968).

(4) HAMMOND E. and ROBSON, T. D.: The Engineer (London), 199. N. ${ }^{\circ} 5165,78-80$ and N. $5166-114-115$ (1955).

(5) MONFORE, G. E.: Journal of the PCA Research and Development laboratories. pp. 35 (May 1968).

(6) GJORV, O.: Nordisk Betons, 2-4, pp. 147 (1982).

(7) ROBERS, J. J.: Cement and concrete association, Technical Report N. ${ }^{\circ} 532$, May (1980).

(8) MOLINA A., ANDRADE C., ALONSO C. and GONZALEZ J. A.: Rev. Tec. Ing. Univ. Zulia Vol. 8, N. ${ }^{\circ}$ 2, 1985. 